Husbandry: A (Feminist) Reclamation of Masculine Responsibility for Care

Julie A. Nelson

WORKING PAPER 2015-01

DEPARTMENT OF ECONOMICS

UNIVERSITY OF MASSACHUSETTS BOSTON 


\title{
Husbandry:
}

\section{A (Feminist) Reclamation of Masculine Responsibility for Care}

\author{
Julie A. Nelson \\ Professor and Chair \\ Department of Economics \\ University of Massachusetts Boston \\ 100 Morrissey Blvd. \\ Boston, MA 02125 USA \\ Julie.nelson@umb.edu
}

March 26, 2015

\begin{abstract}
While extremely important and revolutionary, much feminist work on the economics of care has risked reinforcing an association of care with only women and with only women's traditional activities. This essay revives the image of "husbandry," understood as careful cultivation, tending, and management, as a complement to the image of mothering. A rich masculine prototype of care may be helpful in re-awakening male responsibility for care, and revitalizing the recognition of the necessity of concern and carefulness in all of economic life. The "good husbandman," in stark contrast to "economic man," lives a fuller life, acting responsively and responsibly. This essay lays out the need for such a rich image; suggests applications to the environment, carework, and business management; and addresses some possible drawbacks.
\end{abstract}

\section{Keywords}

care; masculinity; gender; husbandry

JEL codes

A13, B54 


\section{Introduction}

What is the place of care in the economy? Much feminist work so far on the economics of care, while extremely important and revolutionary in its own right, risks implicitly reinforcing an association of care with only women and with only women's traditional activities. The central image has been one of "mothering" (Ruddick 1989, Noddings 2010). The focus has been on hands-on care of children, the sick, and the elderly. Men who participate in hands-on carework, then, while they may be recognized, are treated as somewhat anomalous. What is more, an implicit—and sometimes explicit—belief is expressed that the traditionally masculine realms of business and commerce (as well as sports and warfare) are in some essential way orthogonal to, or inimical to care. ${ }^{1}$ This essay challenges these associations.

Ethics, at their most powerful, originate with, and resonate with, metaphors, images, myths, and narratives that describe who we are and who we should be as people (Nussbaum 1992, Lakoff and Johnson 1999). These contribute to the creation of the "gut feelings" we have about what is right and what is wrong (Haidt 2001, Gigerenzer 2007). This essay seeks to recover and reclaim the old English word "husbandry" to evoke and promote a masculine-associated ethic and practice of care. Grounded in agrarian and pastoral practice, "husbandry," in the sense used here, means careful cultivation, tending, and management. This rich iconic image of masculine-associated attentiveness in productive activities is in stark contrast to the stripped-down images of homo economicus and the "incentivized" CEO_images that have arisen, I argue, from a deleterious "financialization" of masculinity. 
Recovering the term "husbandry" may seem odd, to the extent the word may be more commonly associated with men's historical legal and social domination of their female marital partners. This essay, however, seeks to recover a different meaning of "to husband," analogous to how gender theorists and activists reappropriated the term "queer," converting it from a slur to a more positive usage.

Lest it be misunderstood, the argument here is not that there exists, at some level of gender "essences," a distinctly "masculine style of care" that we should label "husbandry." Rather, the first goal is to evoke and popularize an rich prototype of care that masculine-gendered people may find to be particularly consistent with their self-image. The second goal is to bolster the recognition of care as an indispensible ingredient of economic activity. ${ }^{2}$ The term "husbandry" is especially useful for this purpose because of its historic link to activities that are easily recognizable as productive and "economic." 3

This essay lays out the need for the reclamation of "husbandry" and then demonstrates how it could change our thinking about environmentalism, carework, and business. Possible drawbacks of this reclamation are discussed as well.

\section{What We've Learned from Feminist Scholarship on Care}

Care, when it is thought about at all within mainstream economics, tends to be both sentimentalized (that is, thought of as primarily a matter of altruistic emotion) and marginalized (that is, considered to belong to the sphere of noneconomic--or at best quasi-economic-activity). For example, in one influential model of household behavior, an actor is motivated-in the usual way posited by mainstream theory--by self-interest in the market, but then turns around and 
behaves as an "altruist" at home (Becker 1981). Debates about CEO pay tend to focus on how to properly "incentivize" self-interested CEOs to act in the interest of their companies, through tailored high compensation schemes. Yet recently two articles have argued that the way to assure that careworkers (such as nurses) act in the interest of the care recipients is to go against pecuniary self-interest and grant only low compensation (Heyes 2005, Brekke and Nyborg 2010). Low pay, they argue, assures that only “altruists" will take caring jobs. Meanwhile, women's time spent caring for families has been excluded from discussions of "work" and "production," and, even now, is still not counted as part of Gross Domestic Product (Bjørnholt and McKay 2014).

A considerable body of feminist work over decades, across the social sciences and humanities (e.g., Tronto 1994, Ruddick 1989, Sevenhuijsen 1998, England 2005) as well as within economics (e.g., 1995, Himmelweit 1999, Folbre and Nelson 2000, Meagher and Healy 2003, Budlender 2010) has challenged this sentimentalization, simplification, and neglect. While there is a general sense that "care activities" are of highest quality when accompanied by, and motivated by, authentic emotional commitments, or "caring feelings," it is also recognized that care work is work. Carework requires time, effort, and, often, a high degree of knowledge and skill to be done well. Carework can only be maintained when it is allocated serious economic resources of time and money (Nelson 1999, Folbre and Nelson 2006).

While this is often forgotten, the work of care is also permeated by personal relations of power-for example, the power of a careworker over the vulnerable 
child or patient entrusted to their care, as well as the power of the person hiring or otherwise financially supporting the careworker over the worker. And carework has been structured by social and institutional relations of power. For example, the potential for women (as a group) to participate in the labor market on an equal basis as men is compromised when the "family responsibilities" of hands-on care are both radically individualized (rather than socially supported) and assigned to women (rather than also to men) (Folbre 1994).

And hands-on, face-to-face carework is crucially important for the rest of the economy, providing the foundation for human survival and flourishing. Liberal economic and political theory has tended to follow the advice of Thomas Hobbes, who wrote "Let us consider men...as if but even now sprung out of the earth, and suddenly, like mushrooms, come into full maturity, without all kind of engagement to each other" (cited in Benhabib 1987). This image of the self as radically autonomous has been called the "separative" self (Keller 1986, Nelson 1992, England 2003). Yet humans simply do not spring out of the earth. Humans are born of women, nurtured and cared for as dependent children, and socialized into family and community groups through carework.

At a more theoretical level, a serious challenge to gender stereotypes reveals that it is not the case that men are purely "individual" (that is, "separative") while women are purely "relational" (or, as it has been called, "soluble," with no identity apart from others). Nor are relations limited to possibilities defined by these poles. Consider how Classical liberal political and economic theory considers people to be equal, non-interdependent peers ("separative-separative"), erasing relations of 
dependence, interdependence, and power. Relationships that are asymmetric in power, such as husband-wife (traditionally) or employer-worker, have tended to be understood as hierarchical in a dominating way ("separative-soluble"). Holistic alternatives ("soluble-soluble"), in imagining merger, erase individual agency (Nelson 2005, Nelson 2010). A serious consideration of care, however, reveals that we are all, every one of us, neither mythically separative nor mythically soluble, but rather are individuals-in-relation (Nelson 2010). We all require care at some points in our lives, and are also capable of choice and agency, and of giving care.

This analysis raises a possibility of a form of relationship that is invisible from within a mindset stuck in separative/soluble thinking: the possibility of asymmetric mutuality (Nelson 2005, Nelson 2010). Some relations are hierarchical in terms of power, yet the person holding the power does not choose to use it to dominate, but instead respects and possibly even nurtures the weaker party. This has been an inadequately recognized insight of the care literature. The relationship between a caregiver and a person who is in need of their care (e.g. a child) is not one of symmetry in power, nor is it one of merger. Yet it does not have to be one of domination. The far-ranging implications of recognizing this possibility within economics will be discussed below.

\section{The Need for a Vivid Image of Husbandry}

Feminist work has revealed that care is clearly both crucially important and deeply entwined with economics and politics. Yet, it is a basic fact of human psychology that people tend to pay the most attention, and feel the most affinity with, suggestions that are consistent with our pre-existing beliefs, sense of identity, 
and values. To the extent that the feminist focus on "care" has so far privileged a feminine gender identity, it may awake a response (whether conscious or not) of "not for me" or "not my responsibility" among most men. In addition, to the extent that the feminist economics focus on care has, to date, also been oriented towards traditionally feminine areas of childcare, health, education and the like, the crucial role of care in the traditionally masculine-encoded sphere of the economy has been largely overlooked or even denied.

Given the serious problems in the world-including not only discrimination and deficits in health and education, but also rising inequality, climate change, souldeadening consumerism, war and the threat of war-neither assigning the work of care to only half the population, nor narrowing it to particular spheres of life, can be tolerated.

Arising in agrarian and pastoral societies, "to husband" means, according to the Oxford English Dictionary, "To till (the ground), to dress or tend (trees and plants), to manage as a husbandman; to cultivate." The image evoked is of the yeoman farmer who carefully nurtured the growth of his crops, the Biblical shepherds who watched over their sheep, the nomads who herd and tend their cattle in the Serengeti. Picture this "husbandman" calling his dog, his horses, or his cattle by name. Picture him knowing intimately the challenges of drought and flood, the lore concerning breeding and protection, and the shape of his landscape. Picture him as both working hard to bring forth the necessities of life for his family and community, and doing this in a way that works alongside of, and respects, the natural forces at play and the non-human beings in his care. ${ }^{4}$ 
Unfortunately, a very different image and myth about the role of men in production gained ascendance in the West in the period following industrialization. A dominant pattern emerged in which men left the home and farm to work in factories and commercial establishments, while women--when their families could afford it--remained in charge of child rearing and household management. During the Victorian era, this led to an ideology of "separate spheres," with commerce being envisioned as properly masculine and the place where norms of self-interest and competition should reign, and the home being, conversely, imagined as consistent with an essential feminine nature, and ruled by norms of altruism and cooperation.

How odd, when you think about it, that human nature should be thought of as so wildly bifurcated. Do we really divide ourselves so sharply at the household front door?

This ideology was helped along by the profession of economics. The idea of the economy as a mechanical system driven by the "energy" of self-interest and regulated by "market logic" and the "forces of competition" had been in ascendancy, starting with (a very limited reading of) Adam Smith, through Karl Marx and John Stuart Mill. ${ }^{5}$ In the late 1800 s, Neoclassical economic theory took as its central image of production the activities of "the firm," envisioned as an agent pursuing a single goal, that of maximizing profit. Not only—as many commentators have pointed out-were the concerns of the earlier Classical economists with wealth and distribution shoved aside, but the image of the individual producer as a responsible, careful husbandman was progressively erased as well. Relations within firms were also modeled in ways that radically over-simplified them, draining them of the 
possibility of care. Rather than relations of independence and sociality among human beings, economists have assumed that intra-firm relations reflect, variously, a case of unitary decision-making, or a dominating hierarchy of boss versus worker, or the existence of (impersonal) internal markets.

Recently, there has been much discussion about the "the financialization of the economy" (Denning 2014, Epstein 2006). But notice how the transition from the image of the husbandman to the image of the robotic profit-maximizer, or equally robotic industrial worker, financialized masculinity. Rather than a man embedded in rich relationships with family, land, animals, and purposive activity we now have a man whose main (or even exclusive) role in the family is to be the "breadwinner," and whose role in the larger economy is envisioned as "making money." While this left men, as a group, in a relatively more economically powerful position than women, as a group, it also stripped them of their full humanity. "Man the Paycheck" and "Man the Cuthroat CEO" are limiting, stereotypical images, as damaging in their own way as "Woman the Helper" and "Woman the Dependent."

Times have changed since agrarian and pastoral days, so the "husbandman" image needs some updating. Economies have shifted to include large industrial and service sectors, and globalized corporations and markets. Family norms and social institutions that formerly gave the householder/husband power over the housewife have evolved as well. But what is important to recover from the contrast between "husbandman" and homo economicus is the notion of care-both in the sense of concern, and in the sense of carefulness--as an essential aspect of masculineencoded identity and activity. 


\section{Application: Environmental Stewardship}

Do a Google search on "husbandry," and you will find it in active current use, mostly referring to careful stewardship of animals and/or agricultural crops and land. What could this mean for economics?

In fact, feminist theorizing about care has been directly applied to the question of human-animal relationships recently, through the work of animal ethicist Raymond Anthony $(2012,2009)$ and his coauthors (Gjerris et al. 2011). Anthony directly draws on sources including Martha Nussbaum's work on narrative ethics (Nussbaum 1992), on pioneer works on the human-animal relation by the likes of Donna Haraway and Jane Goodall, and on Sara Ruddick's and Joan Tronto's generative work on care and mothering, to create an image of "diligent husbandry" that can be drawn on to establish a better "human-animal relationship" (Anthony 2009). Borrowing from the care literature, good husbandry is envisoned as characterized by respect, compassion, justice, attentiveness, responsibility, competence, and responsiveness (Gjerris et al. 2011). Anthony and his co-authors contrast this ethic of husbandry with an industrial ethic that, in its most extreme form, treats animals as no more than meat production machines.

One might also gain insight into, and support for, an ecological approach to economics by considering what the Merriam Webster dictionary (2015) lists as antonyms for "to husband." These include to "blow, dissipate, fritter (away), lavish, misspend, run through, squander, throw away, waste." There are good arguments to be made that the current generation on earth (and especially the most 
wealthy among us) are current doing just that with the endowment of natural resources and productivity that we received from our ancestors. "Economic man" dissipates. "The good husbandman" does not.

To some, the recovery of "diligent husbandry" might not go far enough. Some may condemn any instrumental use of other sentient species, demanding absolute equality. Any notion that "asymmetric mutuality" between species could be possible may be dismissed as a demeaning paternalism, akin to defenses of slavery or male dominion over women. Absolute equality among every sentient being, however, is only possible in some world other than the one in which we live. The world in which we live contains children, and contains animals whose capacities are different from our own. Paternalism is not only not demeaning, it is actually unavoidable and-if accomplished with appropriate care and diligence-totally appropriate and healthy in the relationship of a pater to his child. The notion of good animal husbandry extends aspects of this image of respectful and even loving care to relations among species.

\section{Application: Carework}

Another Oxford English Dictionary definition of "husbandry" is "the administration and management of a household; domestic Economy" (2014). This definition is-not surprisingly--cross-referenced to a nearly identical one for "housewifery."6 In pre-industrial times, keeping the household sustained and nourished was a whole-family project. 
While some of that sense of a joint project was lost in the intervening centuries, in recent decades the meaning of fatherhood has been changing again. More women have entered the paid labor force. Old gender norms are eroding. Household technology has substituted for some forms of carework, while non-family sources of childcare and healthcare have become more available. As a result, the Victorian era breadwinner/homemaker divide has become more blurred.

But it could change more. Much feminist writing has focused on the need for men to take on their fair share of household responsibilities, if women are to achieve parity with men in paid employment and attain equivalent levels of economic security and power. And this is a very good point. Yet concern for women's well-being need not be the only motivation for change. Any man who wants to be more than the narrow, financialized "Man the Paycheck" should actively resist being denied the opportunity to exercise his capacity for masculine care in regards to his spouse and his children, his pets and garden. Care can mean more than mowing the lawn; cooking does not require a pink apron; the challenge of changing a heavily soiled diaper or dealing with squabbling children should be seen as something that requires true "manning up."

In paid carework, as well, a "both/and" understanding of human motivation opens new possibilities (Nelson 1999). It means that providing quality care-for example, by enacting careful husbandry through employment in childcare, healthcare, or education--should not be seen as inimical to earning a decent paycheck. Nor should the jobs be seen as effeminate. 
Family carework is intertwined with environmental care in an interesting way in the work of environmental ethicist Hans Jonas. After extensive discussions of rational principles, Kant, and so on in his Imperative of Responsibility, Jonas ultimately claims that the type of ethics that we need for environmental sustainability comes from quite a different source:

[A]ll proofs of validity for moral prescriptions are ultimately reduced to obtaining evidence of an 'ontological' ought...[W] hen asked for a single instance....where the coincidence of 'is' and 'ought' occurs, we can point at the most familiar sight: the newborn, whose mere breathing uncontradictably addresses an ought to the world around, namely, to take care of him. Look and you know.

(Jonas 1984)

That is, "the always acute, unequivocal, and choiceless responsibility which the newborn claims for himself" creates "the ought-to-do of the subject who, in virtue of his power, is called to its care" (Jonas 1984). Jonas seems quite unaware of the gender implications of his statements, presenting both parent and child as male. Yet in the process he clearly evokes an image of responsible husbandry, grounded in a visceral perception of the deep interdependence of life, and the totally inegalitarian distribution-between caregiver and the newborn —of the power to act to support and sustain that life. Considering a particular infant, we see hands-on carework; considering generations into the future, environmental awareness is powerfully evoked.

\section{Application: Business Management}

What about the conventionally "economic" realm of business and commerce? An image of business and commerce that has been in ascendancy in recent decades is one of uncontrolled heartlessness, greed, and competition. In this, people are 
treated as no more than interchangeable "labor resources," and the natural environment as no more than a commodity ripe for exploitation. It is often assumed that businesses—right in line with neoclassical economic theories—are driven entirely by the goal of profit maximization, enforced by competition and/or shareholder lawsuits. Businesses themselves are increasingly treated as commodities, bought and sold as profit-making centers with little regard to their unique products, histories, people, or cultures. A progression towards such "Wall Street capitalism" is often treated as unstoppable-considered to be the inevitable result of some superhuman "market logic."

While the recent tendencies in this direction are clear, the process is not inherent in the "nature" of capitalism, and is not unstoppable. The notion of the profit maximizing firm (as well as of the shmoo worker, resource, and product) was, in fact, invented by economists. By assuming very simple models and applying calculus ("maximizing") to an economy envisioned as machine-like, the academic field of economics very deliberately imitated the "hard sciences," - at least in their $17^{\text {th }}$ century Newtonian form. And it created distance for itself from the "softer" social sciences and humanities (Nelson 1993b). Unfortunately, actually looking at how real companies function was not part of this economics research agenda. And the further the influence of economists goes, the more life starts to imitate fiction (Nelson 2015 (forthcoming)).

To see afresh how economies function, consider two additional images that take us beyond economy-as-machine: "Main Street capitalism" and "The Cabal."

Discussions of "Main Street" versus "Wall Street" (or "The City") arose during 
the 2008 financial crisis. The global financial system--dominated by relatively few large banks, investment firms, and insurance companies which employ a relatively small number of workers--melted down. While none of these financial institutions actually produce the goods and services that people need to live, their meltdown had wide-ranging disruptive effects on the-often smaller and less concentrated"Main Street" businesses that do produce them, as well as provide livelihoods to many. Small businesses—epitomized in the small "Main Street" local grocer or barber-were particularly hard-hurt in the credit crunch.

The "Main Street" image of business includes the possibility of husbandry-ascareful-management. Businesses are not, in fact, legally required to make every last possible dollar of profit, nor, for many of them, does market competition force this on them (Nelson 2011, Bratton 2011, Stout 2012). Businesses that are "husbanded" are enterprises or "going concerns" that are maintained for a variety of reasons, of which profit is only one. These may include the pride of creating an important, livegiving product; the creation of good jobs; the expression of creativity; contributing to the community; keeping up a family tradition; or the excitement of a good challenge. Corporate managers have a "fiduciary duty" to manage in the interest of the corporation. While this is often (thanks to the economics profession!) now interpreted as "must maximize profits for the shareholders," it actually means far more. It means that the leaders are entrusted with the management of the company, for the good of all the company, on both financial and nonfinancial matters (Stout 2012). The good husbandman, whether executive or worker, tends and cultivates. The good husbandman does a good, responsible, day's work for a good day's pay. 
"Wall Street" capitalism is far from being the outcome of some neutral, superhuman "market logic" and inexorable "force of competition." A far more accurate picture is to see is at created by "The Cabal" of powerful elites, who want to maintain and extend their power. The concentration of financial markets (and other important markets, such as agricultural marketing and parts of high tech), and the fact that boards of many companies draw from the same small group of the wealthy and powerful, means that appeals to "the law of the market" and the "discipline of competition" are more often than not only smokescreens. The scenarios is often one of too much cozy cooperation (among the elite), rather than of impersonal, fierce competition. $^{7}$

Appeals to "market logic" are, more often than not, simply excuses for neglecting the responsibilities of husbandry. Wages are going below subsistence? "The market made me do it." Oil got dumped in the bay? "From a bottom-line point of view, paying legal settlements is cheaper than investing in prevention." CEO salaries are outrageous? "That's the market price for talent." Stock options are giving the leaders millions? "Self-interested agents will only do good work if they are properly incentivized at all times." Defenders of the bottom-line-only point of view argue that it is too confusing to give CEOs multiple objectives (Fama and Jensen 1983, Jensen 2002). Tough noogies: The world is not a high-school math problem with a single right answer at the bottom of the page.

This financialization of the CEO role is unfortunate, and not only because it has contributed to dramatically widening inequalities in wealth and income. The simplistic "Man the Cutthroat CEO" has been stripped of his full humanity. What 
should be a full human role of diligent husband has become a precarious, externalreward-dependent pathological race to status (Knights and Tullberg 2012). A worker, as well, turned into "Man the Paycheck," sheds all dimensions of responsibility for the quality of his work, loyalty to his employer, and concern for his coworkers.

Only relatively recently have scholars begun to bring together care theory and business (e.g., Hamington and Sander-Staudt 2011). Only relatively recently has economics begun to look at the non-pecuniary emotional and social dimensions of employment (e.g., Fehr and Falk 2002, Akerlof 1982). ${ }^{8}$

\section{Caveats and Warnings}

Could the reclamation of "husbandry" as a positive, masculine image of care wind up badly? Certainly. At least four problems can be easily predicted: manipulation, domination, marginalization, and essentialization.

\subsection{Manipulation}

While, when thinking of civilian homes and businesses, it is women who are stereotyped as more "altruistic" than men, when talk turns to the military the case reverses. It may be admitted that a woman may, due (presumably) to her essential nature, sacrifice for those she personally loves. But we hear that a man will choose to sacrifice his very life for higher ideals, such as the good of the country.

There are many problems with this image. One is the identification of "care" with "sacrifice." The feminist literature has spilled a good deal of ink discussing the pathologies of the co-dependent, doormat caregiver who does not count her own 
well-being as being among her responsibilities. Instead of contrasting selfish, separative "self-interest" and sacrificing, soluble "altruism," a more realistic view of human nature considers more options. Howard Margolis (1982) suggested that a model of human behavior as "neither selfish nor exploited"—-that is, we have a tendency to watch out for the welfare of others, as long as we do not feel that we are the only ones doing do.

Another problem is the idea that soldiers are motivated primarily by lofty principles. In actuality, one of the strongest motivations_and sometimes the only motivation-for keeping soldiers fighting is their care for each other (Wong et al. 2003). This bonding among war buddies, as well as the care and trust that can develop between soldiers and their commanders, is commendable. It is also highly exploitable and manipulable. Nancy Folbre (2001) has discussed how caring relations between vulnerable people and their caregivers can make the caregivers "prisoners of love" - unwilling to, say, go out on strike for living wages because it would leave their charges in the lurch. Similarly, soldiers who have long since stopped believing that "higher principles" are behind a particular war may yet be manipulated into continuing to fight to protect their buddies. A similar dynamic, though less intense, may also go on at civilian workplaces.

What this means is that the attitudes of husbandry and care, to work well, must permeate all levels of management and government. Opportunistic leaders manipulating their minions into providing care will eventually lead to bitterness, and to the "tapping out" of care as people realize that they have been exploited. 


\subsection{Domination}

Could asymmetric mutuality go wrong? Most certainly.

This essay argues that unequal, but respectful and caring, relations to children, animals, and others (such as the frail elderly) who differ in levels of capability vis a vis functioning prime-age adult humans are not only possible, but may be manifestly and uniquely appropriate. The good husbandman is in a position of greater power than those he cares for, and uses this power for good.

Of course, once one allows this possibility, those who want more power will try to classify more groups as belonging in the dependent and less capable category. Historically, all women and all groups classified as slaves or primitives (e.g., "The White Man's Burden") were put under condescending, paternalistic "care"—losing rights to autonomy and self-definition in the process.

What this means is that appealing to "husbandry" is far from a cure-all. Its appropriateness for any particular case must be carefully explored and critiqued.

\subsection{Marginalization}

If "husbandry" becomes mainstream, does that mean that women and women's contributions will again be marginalized? Will care become the male norm, with women again ignored? Will men be perceived as "thinking of it first" and "doing it better"?

Unfortunately, there is already evidence of tendencies in this direction. For example, Luigino Bruni and Robert Sugden (2008) rediscover the importance of social bonds in markets. Only minimally citing the decades of feminist work on care, 
they label their newfound phenomenon as "fraternity." Henk Jochemsen (2013) explores principles of care in animal husbandry, describing at length Joan Tronto's (1994) pathbreaking four-category description of the dimensions of care. As it's source, he cites Raymond Anthony (2012) not Tronto.

So feminists, in particular, should be leery of misuses of the idea of husbandry that may work against the hard-earned, long-deserved recognition of women, of women's traditional activities, and of women's advances in theorizing care. Yet I believe feminists should, on the whole, welcome "husbandry" as an image that moves us from ideas of men "helping" with care to men actually being responsible for care. Such a paradigm change would get us a long way towards better families, better businesses, and a better relation with the rest of the natural world.

The effects of sexist biases in academic research and citation practices is not likely to go away, though it could be guarded against with more attention. Whether the benefit of reclaiming "husbandry" will ultimately outweigh the cost of possible marginalization of the feminist work on care can only be determined with the passage of time, and by the amount of energy put into keeping the theory on track.

\subsection{Essentialization}

When I first came to feminism in the 1970s, many feminists thought that we would eventually transcend any talk of "masculine" or "feminine" and recognize people and traits in entirely non-gender-differentiated ways. Instead of ideas of men and women as different, androgyny would reign. Any talk of a "masculine" image of "husbandry" may, therefore, be misunderstood by those with a bent towards the 
androgeny as a naïve surrender to outdated gender beliefs. The charge of "essentialism" - that is, of assuming that men and women have distinctly different "natures" that translate easily into distinct sets of appropriate behaviors, occupations, and so on-may therefore be (wrongly) launched against this essay.

Alternatively, the idea of "husbandry" may also be rejected by those who hold strongly essentialist beliefs. Some may prefer to continue to believe that caring is compatible only with a presumably relational and emotional feminine nature, as opposed to a more autonomous and rational masculine nature. In my view, however, theorists who stake out the realm of care as in some way "essentially" womanly advocate a feminine approach, not a feminist one. Such theories further exaggerate differences between men and women, and between the economy and care, with harmful results.

Or the idea of "husbandry" might be found appealing for the wrong reasons. Some may want to essentialize husbandry. A literature could grow up claiming that women have one "style" of care, while husbandry refers to men's "style." This would start with some observations of differences, on average, in male and female time use or perceived modes of engagement with children (under current cultural conditions). It would then likely proceed—based on prior beliefs, apparent plausibility, and cherry-picked data--to claim that evolutionary theory and neuroscience show that men are made to do "husbandry" while women are essentially "mothering." And, likely as not, the claim would be made that "husbandry" is compatible with business management and mowing the lawn, but 
not child care or elder care, and vice versa for "mothering." This would be unfortunate, and should be resisted. ${ }^{9}$

This essay advocates neither an androgenous nor an essentialist position, because both these positions ignore two important facts:

- First, the idea of a strict masculine/feminist gender binary is a creation of our minds. It is an extremely strong and widespread cognitive and social construction. We use it, in deep and systematic ways, to organize our conceptual and social worlds as well as our self-identities (Prentice and Miller 2006). The fact that it is therefore unlikely to go away simply because we might wish it to challenges the strict androgynists. Meanswhile, more recent work on varieties of gender (e.g., including queer, trans, cis, and so on) challenges the notion, held by essentialists, that the binary is not socially constructed but rather is something intrinsically "out there," an underlying fundament of the world.

- Second, "absolutely the same" (androgyny) and "totally distinct" (essentialism) are not the only alternatives. People do hold strong stereotypes about gender differences. In the realm of actual identity and behavior, however, small differences, detectable only "on average," along with a great degree of gender similarity and large ranges of overlap between men and women are more the norm (Hyde 2005, Nelson 2014, Carothers and Reis 2013).

The purpose of reclaiming a particularly masculine image of care is not to assert that men care substantially differently, but to create in our minds and hearts a powerful 
image with which men can identify, and which can be used to oppose the financialization of masculinity and the economy.

Can a woman "husband?" The testimony of female farmer and ranchers, at the least, would answer "yes," though this may or may not be the most appealing image to many women. Because this is not an argument about "essences" or about "styles" of care, it does not imply that women are, as a group, at any disadvantage compared to men, as a group, when it comes to carefully "husbanding" a major business or other powerful organization.

\section{Conclusion}

To the extent that the care literature in economics has focused on women, it may seem to imply that a man would need to become a "male mother" to fully participate-much as women have often had to earn a status as an "honorary male" before they are allowed to exercise economic or political power. To the extent that the care literature has, so far, concentrated on areas such as childcare, health, and education, it may imply that care is not present in, and not necessary for, human activity in more traditionally "masculine" markets and business. This essay challenges these views.

Caring is a human trait, and care is a human responsibility, in all areas of life in which we may find ourselves. Men who neglect their capability to care are less fully men. An economy that neglects care advances towards only towards greed, robotic work, and ecological destruction.

The place of care in the economy is everywhere. 


\section{References}

2014. Oxford English Dictionary.

Akerlof, G.A. 1982. Labor Contracts as Partial Gift Exchange. Quarterly Journal of Economics, vol. 97, no. 4, 543-69.

Anthony, R. 2009. Farming Animals and the Capabilities Approach: Understanding Roles and Responsibilities through Narrative Ethics. Society and Animals, vol. $17,257-278$.

---. 2012. Building a Sustainable Future for Animal Agriculture: An Environmental Virtue Ethic of Care Approach within the Philosophy of Technology. J Agric Environ Ethics, vol. 25, no. 123-144.

Becker, G.S. 1981. A Treatise on the Family. Cambridge, Mass., Harvard University Press.

Benhabib, S. 1987. The generalized and concrete other: The Kohlberg-Gilligan controversy and feminist theory. In Feminism as Critique: On the Politics of Gender, eds. S. Benhabib \& D. Cornell. Minneapolis, University of Minnesota Press.

Bjørnholt, M. \& A. McKay. 2014. Counting on Marilyn Waring: New Advances in Feminist Economics. Bradford ON: Demeter Press.

Bratton, W.W. 2011. At the Conjunction of Love and Money: Comment on Julie A. Nelson, Does Profit-Seeking Rule Out Love? Evidence (or Not) from Economics and Law. Washington University Journal of Law and Policy, vol. 35, 109-115.

Brekke, K.A. \& K. Nyborg. 2010. Selfish bakers, caring nurses? A model of work motivation. Journal of Economic Behavior \& Organization, vol. 75, no. 3, 377394.

Bruni, L. \& R. Sugden. 2008. Fraternity: Why the Market Need Not Be a MoralityFree Zone. Economics and Philosophy, vol. 24, 35-64.

Budlender, D. 2010. Time Use Studies and Unpaid Care Work. London: Routledge.

Carothers, B.J. \& H.T. Reis. 2013. Men and Women are from Earth: Examining the Latent Structure of Gender. Journal of Personality and Social Psychology, vol. 104, no. 2, 385-407.

Denning, S. 2014. Why Financialization Has Run Amok. In Forbes.

England, P. 2003. Separative and Soluble Selves: Dichotomous Thinking in Economics. In Feminist Economics Today: Beyond Economic Man, eds. M.A. Ferber \& J.A. Nelson, 33-59. Chicago, University of Chicago Press.

---. 2005. Emerging Theories of Care Work. Annual Review of Sociology, vol. 31, 381399.

Engster, D. 2007. The Heart of Justice: Care Ethics and Political Theory. Oxford, Oxford University Press.

Epstein, G.A. 2006. Financialization and the World Economy. Cheltenham, Edward Elgar.

Fama, E.F. \& M.C. Jensen. 1983. Separation of Ownership and Control. Journal of Law and Economics, vol. 26, 301-325. 
Fehr, E. \& A. Falk. 2002. Psychological foundations of incentives. European Economic Review, vol. 46, no. 4-5, 687-724.

Fine, C. 2010. Delusions of Gender: How Our Minds, Society, and Neurosexism Create Difference. NY, W.W. Norton.

Folbre, N. 1994. Who Pays for the Kids? Gender and the Structures of Constraint. London, Routledge.

---. 1995. "Holding Hands at Midnight": The paradox of caring labor. Feminist Economics, vol. 1, 73-92.

---. 2001. The Invisible Heart: Economics and Family Values. NY, The New Press.

Folbre, N. \& J.A. Nelson. 2000. For Love or Money - Or Both? Journal of Economic Perspectives, vol. 14, no. 4, 123-140.

Folbre, N. \& J.A. Nelson. 2006. Why a Well-Paid Nurse is a Better Nurse. Nursing Economics, vol. 24, no. 3, 127-130.

Gigerenzer, G. 2007. Gut Feelings: The Intelligence of the Unconcious. NY, Penguin Books.

Gjerris, M., C. Gamborg, H. Röcklinsberg \& R. Anthony. 2011. The Price of Responsibility: Ethics of Animal Husbandry in a Time of Climate Change. J Agric Environ Ethics, vol. 24, 331-350.

Haidt, J. 2001. The Emotional Dog and Its Rational Tail: A Social Intuitionist Approach to Moral Judgment. Psychological Review, vol. 108, no. 4, 814-834.

Hamington, M. \& M. Sander-Staudt. 2011. Applying Care Ethics to Business. In Issues in Business Ethics. Dordrecht: Springer.

Held, V. 2005. The Ethics of Care: Personal, Political, Global. New York, Oxford University Press.

Heyes, A. 2005. The Economics of Vocation or 'Why is a Badly Paid Nurse a Good Nurse'? Journal of Health Economics, vol. 24, no. 3, 561-569.

Himmelweit, S. 1999. Caring Labor. The Annals of the American Academy, vol. 561, no. January, 27-38.

Hochschild, A.R. 2003. The Commercialization of Intimate Life. Berkeley, CA, University of California Press.

Hyde, J.S. 2005. The Gender Similarities Hypothesis. American Psychologist vol. 60, no. 6, 581-592.

Jensen, M.C. 2002. Value maximization, stakeholder theory, and the corporate objective function. Business Ethics Quarterly, vol. 12, no. 2, 235-256.

Jochemsen, H. 2013. An Ethical Foundation for Careful Animal Husbandy. NJAS Wageningen Journal of Life Sciences, vol. 66, 55-63.

Jonas, H. 1984. The Imperative of Responsibility: In Search of Ethics for the Technological Age. Chicago, University of Chicago Press.

Keller, C. 1986. From a Broken Web: Separation, Sexism and Self. Boston, Beacon Press.

Knights, D. \& M. Tullberg. 2012. Managing masculinity/mismanaging the corporation. Organization, vol. 19, no. 4, 385-404.

Lakoff, G. \& M. Johnson. 1999. Philosophy in the Flesh: The Embodied Mind and Its Challenge to Western Thought. NY, Basic Books.

Margolis, H. 1982. Selfishness, Altruism, and Rationality: A Theory of Social Choice. Chicago, University of Chicago Press. 
Meagher, G. \& K. Healy. 2003. Caring, controlling, contracting and counting: Governments and nonprofits in community services. Australian Journal of Public Administration, vol. forthcoming.

Nelson, J.A. 1992. Thinking About Gender. Hypatia: A Journal of Feminist Philosophy, vol. 7, no. 3, 138-154.

Nelson, J.A. 1993a. The Study of Choice or the Study of Provisioning? Gender and the Definition of Economics. In Beyond Economic Man, eds. M. Ferber \& J.A. Nelson, 23-36. Chicago, University of Chicago Press.

Nelson, J.A. 1993b. Value-Free or Valueless? Notes on the Pursuit of Detachment in Economics. History of Political Economy, vol. 25, no. 1, 121-145.

---. 1999. Of Markets or Martyrs: Is it ok to pay well for care? Feminist Economics, vol. 5, 43-60.

---. 2005. Interpersonal relations and economics: comments from a feminist perspective. In Economics and Social Interaction, eds. B. Gui \& R. Sugden, 250261. Cambridge, Cambridge University Press.

---. 2010. Getting Past 'Rational Man/Emotional Woman': Comments on Research Programs in Happiness Economics and Interpersonal Relations. International Review of Economics vol. 5, no. 2, 233-253.

---. 2011. Does Profit-Seeking Rule Out Love? Evidence (or Not) from Economics and Law. Washington University Journal of Law and Policy, vol. 35, no. 69, 69-107.

---. 2014. The Power of Stereotyping and Confirmation Bias to Overwhelm Accurate Assessment: The Case of Economics, Gender, and Risk Aversion. Journal of Economic Methodology, vol. 21(3), no. 3, 211-231.

--- 2015 (forthcoming). Poisoning the Well, or How Economic Theory Damages Moral Imagination. In The Oxford Handbook of Professional Economic Ethics. Online prepublication: http://www.oxfordhandbooks.com/view/10.1093/oxfordhb/97801997666 35.001.0001/oxfordhb-9780199766635-e-008, eds. G. DeMartino \& D. McCloskey. Oxford, Oxford Univesity Press.

Noddings, N. 2010. The Maternal Factor: Two Paths to Morality. Berkeley, University of California Press.

Nussbaum, M. 1992. Love's knowledge: essays on philosophy and literature. Oxford, Oxford University Press.

Prentice, D.A. \& D.T. Miller. 2006. Essentializing Differences Between Women and Men. Psychological Science, vol. 17, no. 2, 129-135.

Rippon, G., R. Jordan-Young, A. Kaiser \& C. Fine. 2014. Recommendations for sex/gender neuroimaging research: Key principles and implications for research design, analysis, and interpretation. Frontiers in Human Neuroscience, vol. 8, no. Article 650, 1-13.

Ruddick, S. 1989. Maternal Thinking: Toward a Politics of Peace. Boston, Beacon Press.

Sevenhuijsen, S. 1998. Citizenship and the Ethics of Care. New York and London, Routledge.

Stout, L. 2012. The Shareholder Value Myth: How Putting Shareholders First Harms Investors, Corporations, and the Public. San Francisco, Berrett-Koehler. 
Tronto, J. 1994. Moral Boundaries: A Political Argument for an Ethic of Care. NY, Routledge.

Webster, M. 2015. Merriam Webster dictionary

Wong, L., T.A. Kolditz, R.A. Millen \& T.M. Potter. 2003. Why They Fight: Combat Motivation in the Iraq War. ed. S.S. Institute.

${ }^{1}$ For example, sociologist and care theorist Arlie Hochschild, in The Commercialization of Intimate Life (2003), repeatedly frames her argument in terms of a harsh, depersonalized world of intrinsically destabilizing capitalism, versus an ethical, caring world of non-monetized family and community relations: "When in the mid-nineteenth century, men were drawn into market life and women remained outside it," she writes uncritically, "female homemakers formed a moral brake on capitalism" (p. 8). Care theorist Virginia Held (2005) likewise directly associates forprofit enterprise with "market values" which she sees as diametrically opposed to care (p. 111).

2 Several movements now call for a "caring economy"-e.g., Caring Economics (http://www.caring-economics.org), the Caring Economy Campaign (http://caringeconomy.org), and the New Economy Coalition (http://neweconomy.net/new-economy-coalition). While there are some differences in approach among these movements and the current essay, in general this essay should be seen as complementary.

3 The field of economics tends to, these days, be defined in terms of rational choice models or the study of markets. Defining economics as the study of ways in which societies organize themselves to provide for the survival and flourishing of life opens opportunities for more grounded and helpful analysis (Nelson 1993a). 4 This image of good husbandry is deliberately idealized, because it is aspirational. Note that idealizations of good (or good-enough) mothering likewise omit mention of abusive, neglectful, overwhelmed, or otherwise severely deficient mothering. 5 For a discussion of the roots of this image in economists' "physics envy," see Nelson (1993b).

6 The OED goes on to say that a "good husband" goes on to is one "who manages his affairs with skill and thrift; a saving, frugal, or provident man; an economist" (emphasis added).

${ }^{7}$ Unfortunately, many critics of neoliberal policies have themselves been taken in by the neoliberal image of the market as an impersonal machine. As a result, much academic ink has been spilled decrying "inherent market logic," that might have been better used supporting husbandry and Main Street.

${ }^{8}$ Scholars of social policy and politics have been more active in developing theories of care (e.g., Noddings 2010, Engster 2007, Tronto 1994).

${ }^{9}$ Some good resources for this battle include Fine (2010) and Rippon, Jordon-Young, Kaiser, and Fine (2014). 